\title{
Central Place Theory And Southern Urbanization
}

\author{
KENNETH WeIHER*
}

At one time central place theory was a popular topic in the literature on regional science. Numerous efforts were made to refine the model and to test it against the real world. ${ }^{1}$ Such work still appears occasionally [1], [14], [15], [21], [27]. From all this labor we have learned a great deal about the theoretical limitations of the model and about tremendous difficulties involved in trying to prove empirically the existence of a central place system in any particular region. Although we may not be able to provide conclusive statistical verification of city systems constructed along hierarchical lines, we can be quite certain that the economics of location influence urbanization in such a way that all urban systems are molded to some extent by the principles of central place theory.

The esoteric pursuits of central place theory have been carried about as far as they can go, but still we are left with a sterile mass of information and a model that has seldom been applied. For example, in spite of all the data generated by Berry and Garrison, we know nothing about the urbanization process in Snohomish County [8]. Notwithstanding its static limitations, central place theory is above all else a model of urbanization and urban growth. It provides a theoretical framework for the study of the rise and the growth of urban systems by asserting that urbanization is not merely the chance result of population growth and industrialization but is the product of intricate market forces. The model is a potentially useful tool for studying the urban development of a region. In addition, even though it is not a dynamic model, central place theory is more useful when it is applied to an extended period of time rather than to an empirical test of a single date. So far the model has been given very little opportunity to do what it was created to do, determine "the causes of towns being large or small because . . . there are special economic geographical laws which determine the size, distribution, and number of towns" [10, pp. 2-4].

The purpose of this study is to demonstrate that the application of central place theory to the study of urbanization of the American South reveals significant information about the dynamic process of building an urban system in this highly agricultural region. ${ }^{2}$ It can be shown that the city system in the cotton-growing states at the turn of the century conformed to and can be analyzed in the context of the central place

*Assistant Professor, The University of Texas at San Antonio. 
model. Indeed, the only clear way to explain the peculiarities in the rate and form of southern urbanization is to view the historical process as the evolution of a hierarchy of central places, the primary functions of which were to provide central services of the cotton-growing industry. Specifically, this paper (1) reports on the evidence of the development of a central place system in the South from 1880 to 1930, (2) argues that much of the southern urbanization experience is explicable through the application of the central place model, and (3) suggests inferentially that central place theory can be a useful tool in the study of the urban development of a region.

\section{II}

The South draws our attention because of its unusual urbanization record. Early southern urbanization was a slow and uneven process. From 1800 to 1880, the South fell progressively farther behind both the industrial North and the agricultural Midwest in establishing and populating cities. The cotton-growing region was characterized by an abundance of towns (for the purpose of this study, urban places with populations below 4,000) but a scarcity of cities. For example, there were as many cities in the farming state of Indiana in 1880 as there were in eight southern states combined. Urbanization actually came to a halt in the 1870's as Table 1 shows. The situation was considerably different in the period from 1880 to 1930 . During these five decades, the rate of southern urbanization pulled ahead of the pace set by the rest of the country. By 1930 an expanding network of interdependent trading centers had developed. But despite the fifty years of impressive growth, the city system that had developed still retained the property of relatively small and widely-spaced cities.

Table 2 gives a clear impression of the progress of southern urbanization. The percentage of American urban places located in the South fell to barely over 12 percent in the 1870's. Then the rise was extremely rapid over the next fifty years as the percentage doubled. Leading the way, with their percentage more than doubling, were the small cities. Their number jumped from 88 to 602 by 1930 . The larger cities' growth lagged behind the smaller cities, but by 1930 the southern percentage of such cities had climbed to 19 percent. Something occurred around 1880 that stimulated small city development, which in turn spurred the growth of large cities.

The apparent causal relationship between small city growth and large city growth shown in Table 2 suggests the interdependencies of a central place system. The idea that the southern urban system conformed to an extent to the central place model originated with August Lösch's The Economics of Location [19]. He used the southern market areas and city networks to exemplify the existence of central place systems in the real world. If the South can be used as substantiation for the theory, it seems reasonable to expect that the theory can be used to analyze the growth of southern cities. 
TABLE 1

Growth of Urban Population in the United States and Thirteen Southern States

\begin{tabular}{|c|c|c|c|c|}
\hline \multirow[b]{2}{*}{ Year } & \multicolumn{2}{|c|}{ Urban Population } & \multicolumn{2}{|c|}{$\begin{array}{l}\text { Percentage of Population } \\
\text { in Urban Centers }\end{array}$} \\
\hline & $\begin{array}{l}\text { United } \\
\text { States }\end{array}$ & South & $\begin{array}{l}\text { United } \\
\text { States }\end{array}$ & South \\
\hline 1850 & $3,543,716$ & 493,662 & 15.3 & 6.0 \\
\hline 1860 & $6,216,518$ & 742,381 & 19.8 & 7.2 \\
\hline 1870 & $9,902,361$ & $1,013,687$ & 25.7 & 9.4 \\
\hline 1880 & $14,129,735$ & $1,377,982$ & 28.2 & 9.4 \\
\hline 1890 & $22,106,265$ & $2,382,800$ & 35.1 & 13.4 \\
\hline 1900 & $30,159,921$ & $3,339,779$ & 39.7 & 15.2 \\
\hline 1910 & $41,988,932$ & $5,308,070$ & 45.7 & 20.1 \\
\hline 1920 & $54,157,973$ & $7,503,288$ & 51.2 & 25.4 \\
\hline 1930 & $68,954,823$ & $10,827,860$ & 56.2 & 32.1 \\
\hline
\end{tabular}

Source: [26, p. 33]

In terms of its fulfillment of Löschian assumptions, the South provided a very favorable environment for the development of a central place system. The rural landscape of the mid-nineteenth century South was dotted with self-sufficient farmsteads. Each ante-bellum plantation was a community in itself and closely fit the image of Lösch's settlements. These plantations theoretically could have been the foundation of a central place system.

Aside from Lösch's statements, the only opinion on the existence of a central place system in the South comes from the authors of Regions, Resources, and Economic Growth [21]. They note that by 1910 the city systems of the entire north central and northeastern parts of the United States had well-established urban hierarchies, but they contend that in 1910 the cities of the southern and plains states were not parts of "clearcut urban hierarchies." Their assertion may have been accurate for the South of 1870. It can be shown, though, that a clearly defined urban hierarchy was in existence by 1910 . Their inability to recognize such a system was simply a matter of not looking beyond the superficial fact that the South was still decades behind the northern states in the absolute size and number of its cities.

Various kinds of evidence point to a central place system in the South. First, a strong log-linear relationship existed between the rank and size of southern cities. Table 3 shows the results of a series of regressions run on the 100 largest cities in the South. The following equation was used:

$$
\ln \text { population }=\mathrm{a}+\mathrm{b} \cdot \ln \mathrm{rank}
$$

Robert Higgs ran the same test to argue that a "well-defined urban hierarchy" could be found in the plains states [16]. By Higgs' criterion 
TABLE 2

Number of Urban Centers in the U.S. and the Thirteen Southern States

\begin{tabular}{|c|c|c|c|c|c|}
\hline \multicolumn{4}{|c|}{ Number of Urban Places } & \multirow{2}{*}{$\begin{array}{l}\text { Percentage of U.S. Cities } \\
\text { with more than } \\
10,000 \text { Inhabitants } \\
\text { Located in South }\end{array}$} & \multirow{2}{*}{$\begin{array}{l}\text { Percentage of U.S. Cities } \\
\text { with } 10,000 \text { or Less } \\
\text { Inhabitants Located } \\
\text { in South }\end{array}$} \\
\hline Year & U.S. & South & $\begin{array}{l}\% \text { in } \\
\text { South }\end{array}$ & & \\
\hline 1870 & 663 & 80 & 12.1 & 14.3 & 11.3 \\
\hline 1880 & 939 & 119 & 12.7 & 13.9 & 12.3 \\
\hline 1890 & 1,348 & 222 & 16.5 & 15.0 & 17.0 \\
\hline 1900 & 1,737 & 320 & 18.4 & 15.2 & 19.5 \\
\hline 1910 & 2,262 & 480 & 21.2 & 16.8 & 22.8 \\
\hline 1920 & 2,722 & 643 & 23.6 & 18.1 & 25.7 \\
\hline 1930 & 3,165 & 790 & 25.0 & 19.1 & 27.6 \\
\hline
\end{tabular}

Source: [26, p. 28]

of "goodness of fit" the South also displayed such a hierarchy. This test by itself actually proves little, since a rank-size relationship is hardly a sufficient condition for indicating the existence of a hierarchy. Nevertheless, the results do show an orderly progression from a single metropolis to a multitude of small towns.

If the southern city system did conform to the central place model, we would expect that city size and market size would be closely related. In order to test for this relationship, the population of southern cities was regressed against the size of their respective market areas. As Lösch often did, I used the distance separating a city from another city of equal (or greater) size as a proxy for the size of a city's market area. Table 4 shows the results for selected years. City market size explained about 65 percent of the variation in city size. In spite of the many topographical and political irregularities which affected city size and location, the greater portion of a city's growth potential was determined by the size of its market region. This is, after all, the basic premise of central place theory.

\section{TABLE 3}

Results of Regressing Log Rank Against Log Size for Southern Cities, 1870 to 1930

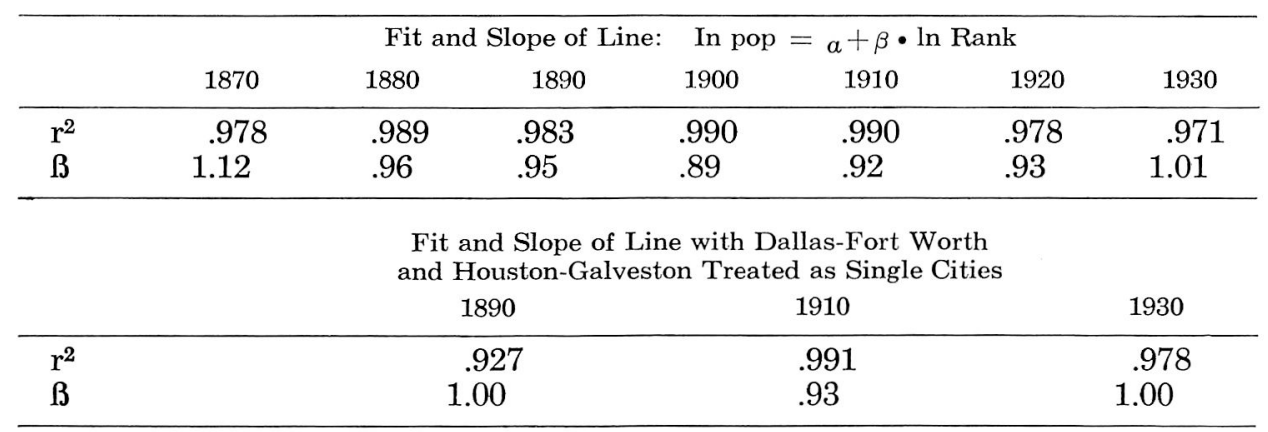


TABLE 4

Results of Regressing Log of Distance Between Cities Against Log of City Population

\begin{tabular}{cccc}
\hline \multicolumn{5}{c}{ Coefficients of Determination } \\
1880 & 1890 & 1910 & $1930 \mathrm{a}$ \\
\hline .650 & .669 & .653 & .631 \\
\hline
\end{tabular}

a: Data for GFSW only.

Throughout the 1880-1930 period, New Orleans was the southern city with the highest population, the largest market area, and the greatest variety of economic activities. It unquestionably was the South's highest order central place. The central place model would predict about four lower-order cities surrounding New Orleans in an evenly-spaced, partial ring. ${ }^{3}$ These cities would be the second through fifth-largest cities in the South. By 1890 such was the case with the urban centers of Atlanta, Memphis, Dallas-Fort Worth, and Houston-Galveston. ${ }^{4}$ As is shown in Figure 1, these four centers lie on an evenly-spaced ring at an average of 365 miles from New Orleans. The four were clearly the dominant urban centers in their sub-regions, and together with New Orleans they served almost the entire South with higher order services. ${ }^{5}$

Surrounding each of the five higher order cities was a network of lower order cities including an easily recognizable third layer made up of twenty-four cities. A portion of this arrangement is illustrated by the map of the Atlanta market region in Figure 2, which shows the thirty-one largest cities in the region in 1890. The resemblance between the Atlanta urban network and Christaller's central place model is striking. After looking at this central place system, it becomes clear that the words used in Regions, Resources, and Economic Growth to describe the northern city systems fit the South far better-i.e., "a broad base of many smaller-sized urban centers underlying a small number of larger cities ranging up to a dominant regional metropolis"' [21, pp. 17-19].

None of this evidence, whether considered separately or taken together, is as convincing or instructive as the information generated by comparing the southern city system to the hierarchy of central services that shaped it, the services of the cotton-growing industry. Lösch noted the connection between southern urbanization and the cotton industry:

Cotton growing for a long time determined the spatial organization of the economy in the American southern states. The supply regions of 15,000 cotton gins, which cleaned the cotton and removed the seeds, were superimposed over the producing areas of the individual plantations; above these came the wider-meshed network of presses; above these again, the 500 oil mills; then the transhipment points; the collecting depots where the cotton is sorted and stored; and, at the top, the two principle export ports with their enormous supply regions. [19, p. 219] 


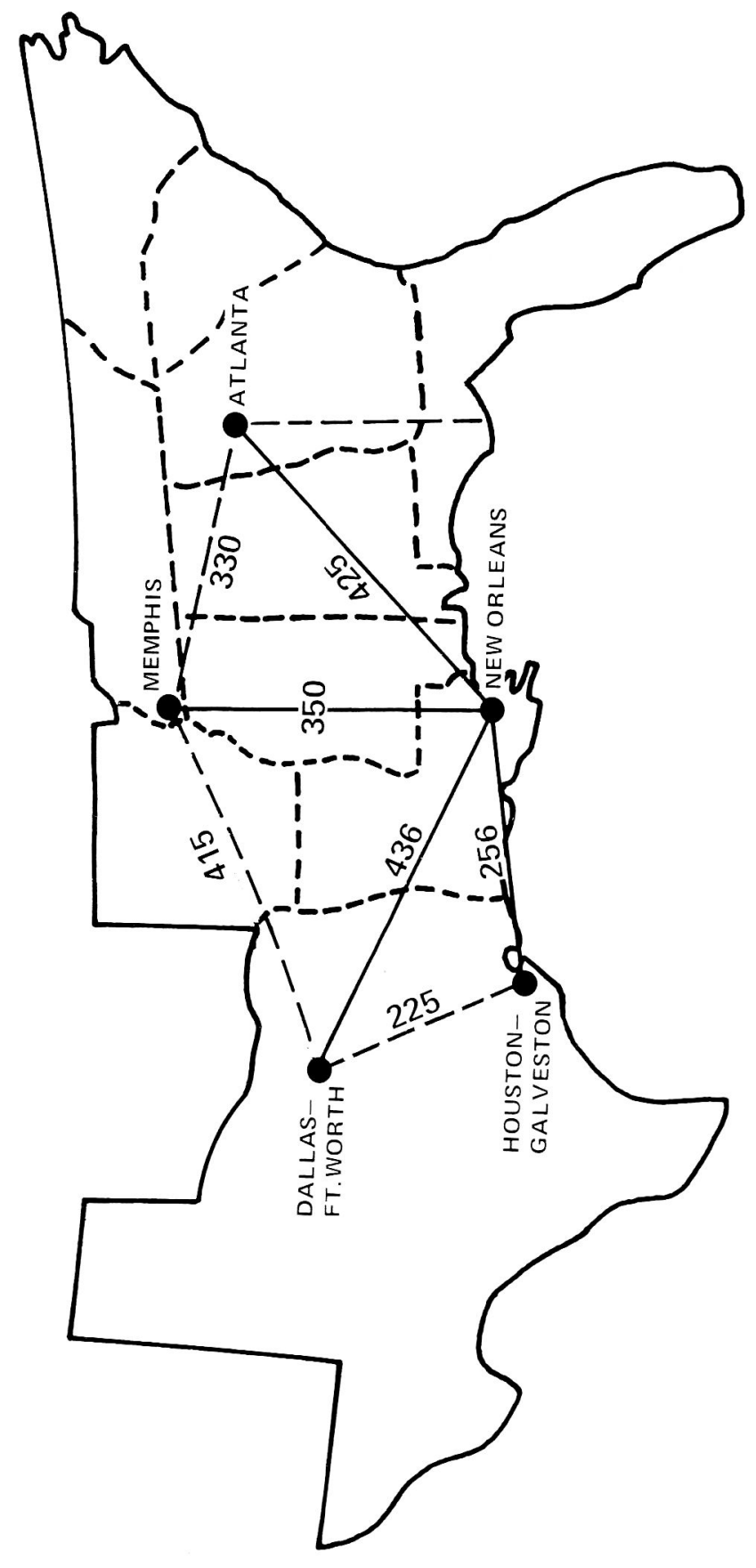

FIGURE 1 The New Orleans Market Area with Distances between the South's Highest Order Cities 


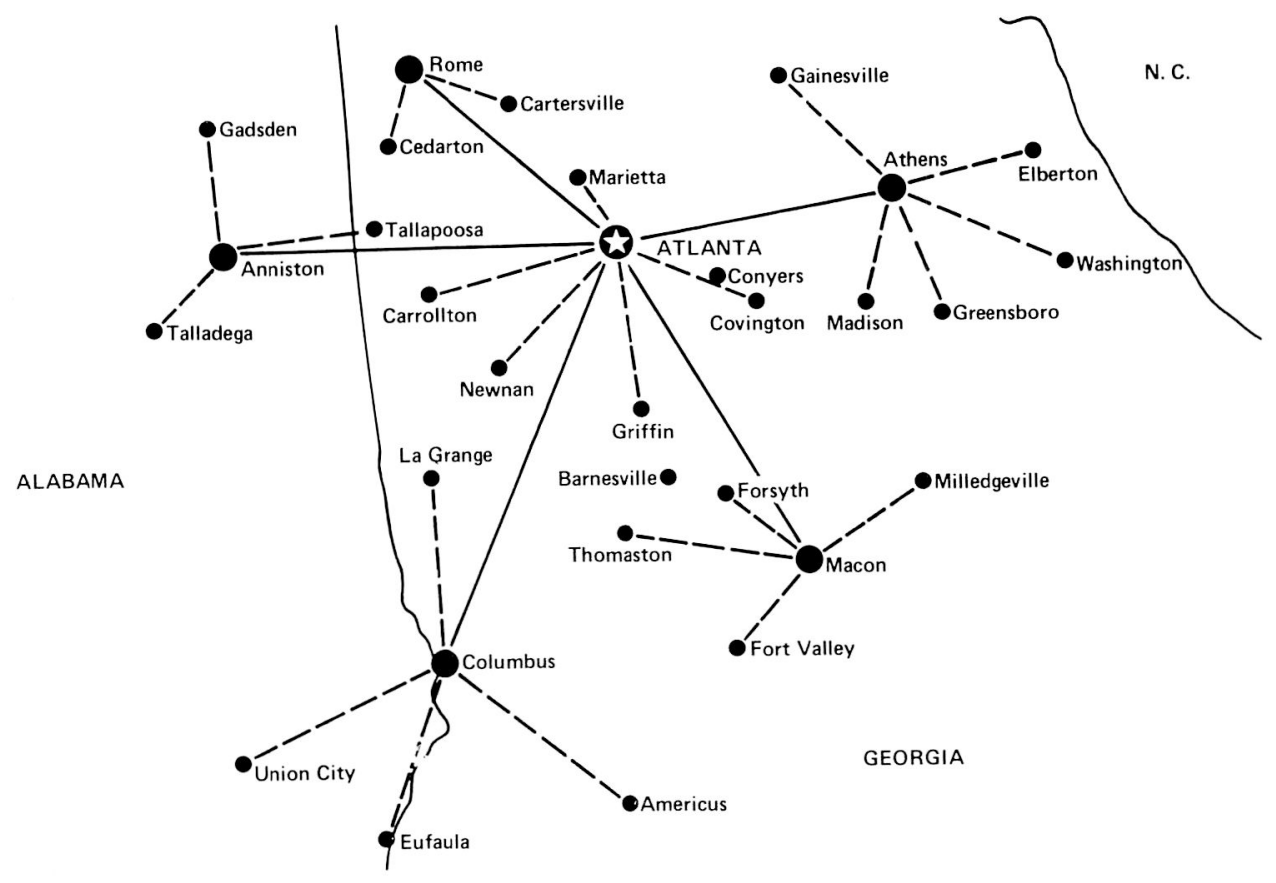

FIGURE 2 The Atlanta Market Area and City System 
There can be no question of the potential influence that the industry wielded at the turn of the century. Moreover, the central functions of the cotton industry possessed at every level many characteristics that correspond to the assumptions, both explicit and implicit, of central place theory. The plantation has already been mentioned. The secondary processes Lösch referred to are all good examples of central functions serving surrounding hinterlands. The plantations and the array of central cotton services were the most influential forces on the form of the southern urban system.

It is possible to delineate a five-tiered hierarchy of cities and functions. The first order was made up of the towns in which cotton gins were located. The cotton gin was the decreasing-cost activity that initiated the planters' break from self-sufficiency. Planters had the choice of cleaning their own cotton or transporting it to the local gin which, because of its larger size, could do the work more efficiently and more cheaply. Gins could be found almost anywhere, but practically every town that had a gin became a market place for cotton as well as for finished goods required by the planters. Thus developed a mesh of first-order central functions and places with their corresponding market areas. These towns generally had populations of $1,000-4,000$ and market radii of five to ten miles.

A layer of larger, more widely spaced urban places arose at the turn of the century. These small cities were the locations of the cotton compresses and cottonseed mills. By 1930 there were over 500 establishments of each, and they were usually located together in the small cities. The increased economic activity attracted by the presses and mills caused the second-order places to be larger and more diversified than the gin towns. By 1930 the population of cities in this group generally ranged from 4,000 to 20,000 .

The gin towns and the press/mill cities fell within the market areas of the twenty-four third-order cities that surrounded the four fourth-order centers of Memphis, Atlanta, Dallas-Fort Worth, and Houston-Galveston as well as the fifth-order city of New Orleans. These twenty-nine higher order centers provided the higher order services of transhipment, storing, selling, and testing as well as the first and second-order services. The connection between the higher order cities and the hierarchy of central cotton services is evident in the data on southern industry and commerce. Figures on cotton bale receipts, for example, indicate which cities were the major transhipment points. Twenty-three of the twentynine highest order cities were listed as leaders in cotton receipts for 1930 in the Commercial and Financial Chronicle. This fact shows that most of the designated higher order centers performed higher order central cotton services.

The importance of the cotton services to the lower order cities shows up best in the data for 1930 from the Gulf-southwest portion of the New Orleans market area. ${ }^{6}$ I refer to this region because the data on the lo- 
cation of cotton services is more complete for that geographical area. Seventy-eight of the ninety-three cities with populations over 5,000 were the sites of cottonseed mills and/or cotton compresses. The four fourth and fifth-order centers located in the region had an average of eight mills and thirteen presses. The eleven third-order cities in the region had an average of 2.6 mills and 1.5 presses. There was an average of .8 mills and .7 presses in the remaining seventy-eight cities with populations over 5,000 .

If the cotton hierarchy and the urban network were as closely related as the preceeding information suggests, we would expect a strong relationship between the size of a city's market area and the kinds and number of central cotton services located in that city. The larger was the market area for a city; the higher should have been its number of receipts, cottonseed mills, and cotton presses. Such was certainly the case in 1930. A series of regression was run on eighty-nine of the ninety-three cities (excluding New Orleans, Memphis, Dallas-Fort Worth, and Houston-Galveston) testing the relationship between the market sizes of the second and third-order cities and the central cotton services provided by the cities. Simple regressions were run which showed significant correlations between the three variables (mills, receipts, and presses) and the market sizes of the cities. ${ }^{7}$ In fact, the number of cottonseed mills present in a city explained over 54 percent of the variations in market sizes.

The results of the multiple regression including all three variables (plus a dummy variable added to account for port cities) show that the presence of a mill and/or a press, the number of cotton receipts and/or a location along the coast explain over 89 percent of the variables in market sizes of cities in the Gulf-southwest portion of the South in $1930 .^{8}$ This test establishes that the market sizes of second and third-order cities were closely related to the position the cities held in the hierarchy of central cotton services. If the results of these tests are combined with our knowledge of the first-order cotton gin towns, which were the primary trade centers of the South, and the fourth and fifth-order cities, which acted as regional centers of sorting, storing, and exporting, it is evident that a hierarchy of central functions and central places coexisted. Not every city fit into the hierarchy, but so many did that there can be no doubt of the existence of a central place system in the South in 1930 and in earlier years.

\section{III}

By showing that the southern city system conformed to the central place model, we have made it possible to use the model to analyze southern urbanization. The reason southern urban growth was so slow before 1880 and so rapid thereafter has never been satisfactorily explained. Through the application of central place theory it is possible to trace the problem to the growth rates of the small cities. 
In 1880 the South had a conspicuous shortage of cities of all sizes but especially of small cities. There was an abundance of small towns, but few of these towns grew beyond a population of $4,000 .{ }^{9}$ One indication of the shortage is that there were in 1880 only eighteen cities with populations of between 4,000 and 10,000. There were, however, twenty-three and thirty-nine towns in the 3,000-4,000 and 2,000-3,000 brackets, respectively. Another indication is the decided gap evident in the 4,000 to 20,000 range of the rank-size distribution of southern cities for years before and including 1880 .

The reason for the shortage of small cities can be found in the hierarchy of central services and central places existing in 1880. It is possible to distinguish only four orders of central functions and places up to 1880: one highest order central port, a group of four major depots, fifteen to twenty transhipment points, and a layer of almost 200 cotton gin towns. The network of presses and cottonseed mills which was earlier shown to be an integral part of the southern urban hierarchy essentially had not been established as of 1880 . After cotton was cleaned and sold at the local market, it was baled and shipped directly to the transhipment points. Thus, the cotton hierarchy supported a very large number of small towns, several transhipment places, and a group of higher order depots and ports. There was no economic reason, at least within the hierarchy of cotton services, for the existence of small cities. What is more, as all of the data indicate, there were scarcely any small cities in 1880 .

Compared to the findings for 1930 , the South of 1880 was missing the second order of central places. A priori, the effects of having one poorly developed order are clear: the growth of higher order places depends on the growth of surrounding sub-places. If for some reason second-order cities are slow to develop, their retarded growth will hold back the growth and development of existing and potential third, fourth, and fifth-order cities. The growth of second-order cities requires that some central functions have minimum market ranges exceeding the areas for the first-order places and maximum ranges falling short of the areas for the third-order places. If there are few second-order cities, the population density of the market area for each third-order place would be virtually limited to the density of the network of first-order places; thirdorder places would be fewer, smaller, and more widely spaced than they otherwise would be. Likewise, the number and size of even higher order places would be decreased.

In order for more of the first-order gin towns to have grown beyond 4,000 residents, higher order functions needed to be established. The South lacked intermediate functions until after 1880. The next-highest order function above ginning and baling was transhipment, which required a very large minimum market area. Necessarily large market areas and low population density kept transhipment points widely spaced, and the static gin towns provided them very little growth impetus. It follows from central place theory that the slow urban growth 
before 1880 and fast growth thereafter were caused by the missing order of cities and the eventual rapid appearance of a great many secord-order cities. In view of the well-defined hierarchies of cities and functions existing in 1930, it also follows that the shortage of small cities was due to the missing order in the hierarchy of central services. The fact that the accelerated urban growth which occurred after 1880 was led by the small cities lends support to the idea that the stagnation before 1880 was caused by the dearth of small cities.

Furthermore, it can convincingly be shown that the rapid growth of the small cities was directly tied to the development of the second-order services of cottonseed milling and cotton compressing. For a variety of historical reasons that are not relevant to this study, these two processes hardly existed before 1880 and burgeoned from 1880 to $1930 .^{10}$ Statistical tests show that the towns in which the two processes were established grew significantly faster than other towns, and the accelerated growth was uniquely concentrated in the decades immediately following the establishment of the processes. These towns made up the overwhelming majority of the second-order cities observed in 1930. This development of the second order acted as a stimulant on the growth of cities of all sizes. The rates of urban growth in the South therefore become easy to explain when the southern city system is viewed in the framework of the central place model.

IV

As was noted earlier, southern cities were characteristically smaller and more widely spaced than cities in other parts of the country even as late as 1930 when the urban system had matured. This fact is not surprising when we consider which central place model the southern city system best fit. Southern cities grew in a spatial organization which naturally led to fewer and smaller higher order cities. An investigation of the pattern of city development in the South reveals crucial determinants of the degree of southern urbanization.

Lösch provided an array of possible patterns urban systems might take, and he emphasized the three most likely possibilities: $\mathrm{k}=3, \mathrm{k}=4$, and $\mathrm{k}=7$ where $\mathrm{k}$ is the number of complete $\mathrm{n}-1$ order market areas served by an $\mathrm{n}^{\text {th }}$-order city including its own market). Figure 3 and Table 5 show the differences among the models. A key difference between the $\mathrm{k}=7$ model and the other two is that in the case of the latter two, neighboring $\mathrm{n}^{\text {th }}$-order places share their surrounding $\mathrm{n}-1$ order places with each other. Each $\mathrm{n}^{\text {th }}$-order city in the $\mathrm{k}=7$ model has six $\mathrm{n}-1$ order cities which lie within its market area alone. Given the same number of first-order places, the higher the value of $k$, the lower the number of cities in all higher orders. In Table 5 , the $\mathrm{k}=7$ model actually produces two less orders than the $\mathrm{k}=4$ model and three less orders than the $\mathrm{k}=3$ model. A city system that follows the $\mathrm{k}=7$ pattern rather than the other two will have fewer large cities. 
Volume 6, Number 2
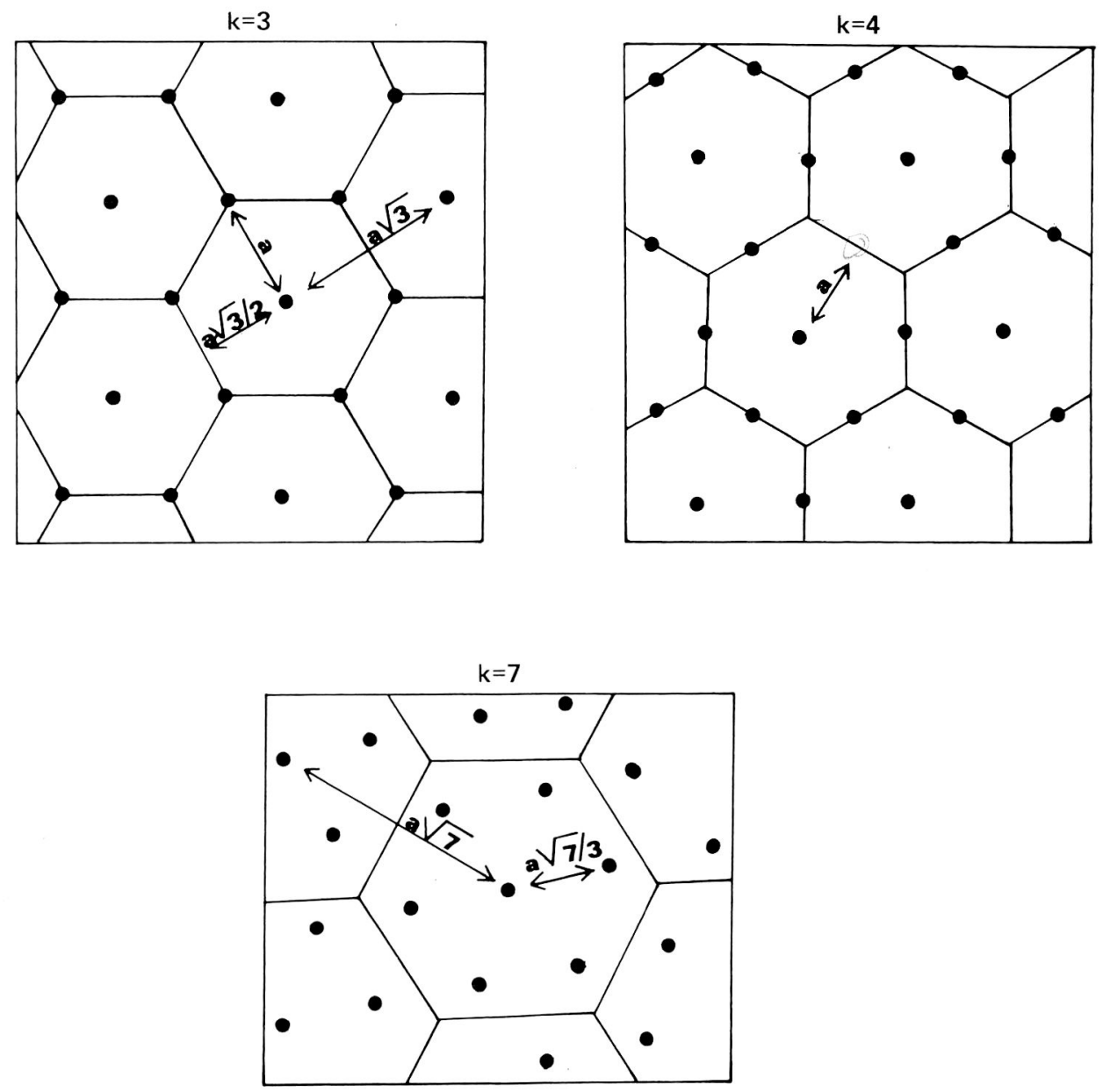

FIGURE 3 Patterns of Central Place System Development 
TABLE 5

Sample Regions with Homogeneous Structures

\begin{tabular}{ccccrrrrr}
\hline & \multicolumn{3}{c}{ Distances Separating } & \multicolumn{5}{c}{ Number of Cities in a Given Order } \\
Centers of Equal Size & $\mathrm{k}=7$ & $\mathrm{k}=3$ & $\mathrm{k}=4$ & $\mathrm{k}=7$ & $\mathrm{k}=3$ & $\mathrm{k}=4$ \\
\hline & $\mathrm{k}=3$ & $\mathrm{k}=4$ & $\mathrm{k}=4$ & & & & \\
1 & $\mathrm{a} \sqrt{3}$ & $\mathrm{a} \sqrt{4}$ & $\mathrm{a} \sqrt{7}$ & 126 & 336 & 2058 & 2058 & 2058 \\
2 & $\mathrm{a} \sqrt{3^{2}}$ & $\mathrm{a} \sqrt{4^{2}}$ & $\mathrm{a} \sqrt{7^{2}}$ & 42 & 84 & 294 & 686 & 515 \\
3 & $\mathrm{a} \sqrt{3^{3}}$ & $\mathrm{a} \sqrt{4^{3}}$ & $\mathrm{a} \sqrt{7^{3}}$ & 14 & 21 & 42 & 229 & 129 \\
4 & $\mathrm{a} \sqrt{3^{4}}$ & $\mathrm{a} \sqrt{4^{4}}$ & $\mathrm{a} \sqrt{7^{4}}$ & 6 & 6 & 6 & 77 & 32 \\
5 & $\mathrm{a} \sqrt{3^{5}}$ & $\mathrm{a} \sqrt{4^{5}}$ & $\mathrm{a} \sqrt{7^{5}}$ & 1 & 1 & 1 & 26 & 8 \\
\hline
\end{tabular}

$a=$ The Distrance Separating the original settlements.

A careful look at the arrangement of southern cities indicates that the central place system existing in the South best fit the $\mathrm{k}=7$ model. Figure 2 of the Atlanta sub-region shows that the five third-order cities surrounding Atlanta lay an average of only seventy-five miles away. Since Atlanta is 300 miles from Memphis and 425 miles from New Orleans, Atlanta obviously could not have been sharing the markets of any of the five third-order places with either Memphis or New Orleans. The $\mathrm{k}=3$ and $\mathrm{k}=4$ models would place the third-order cities approximately midway between Atlanta, Memphis, and New Orleans. Instead, all five lie well within the 200-mile radius of Atlanta's market area.

Throughout the South, there were too many third-order places located too close together for the $\mathrm{k}==3$ and $\mathrm{k}=4$ models to fit. The average distance separating the twenty-four third-order places is 91.4 miles, considerably below the distance predicted by the $\mathrm{k}=3$ and $\mathrm{k}=4$ models as well as by the $\mathrm{k}=7$ model. Second-order cities were spaced almost exactly as the $\mathrm{k}=7$ model predicts. Given the 91.4 miles separating third-order cities, the $\mathrm{k}=7$ model predicts an average distance between second-order cities of 35.5 miles. The actual distance separating cities with populations between 4,000 and 20,000 was 34.1 miles. ${ }^{11}$ Table 6 shows the correspondence between the southern five-tier, central place system and the hypothetical $\mathrm{k}=7$ model. In many ways the arrangement of the southern central place system closely approximated the $\mathrm{k}=7$ model, especially in the lower orders.

Lösch used similar methods to show that the $\mathrm{k}=4$ model best fit Iowa and other midwestern states. If both his assessments and those in this study are correct, we have a very good explanation for the facts that there were fewer larger cities in the South and that urban growth appears to have proceeded more slowly in the South than in the Midwest. The southern city system followed a pattern that resulted in a less highly developed urban network. We are left with the question, though, of why the South followed the $\mathrm{k}=7$ pattern as opposed to the two most likely alternatives, $\mathrm{k}=3$ and $\mathrm{k}=4$. 
A theoretical deduction can be made from Lösch's model about the reason for the value of $\mathrm{k}$ being high in any particular region: the more widely spaced are the first-order places in a region; the greater is the likelihood for $\mathrm{k}$ to be high. Widely spaced first-order places can lead to fewer and smaller higher order places because transport costs are the primary determinants of the size of market areas and the profitability of supply in the areas. By fewer higher order places I mean a lower number of higher order places per first-order place. A low number of higher order places means a high value for k. For example, 1,000 firstorder places located twenty-five miles apart will support fewer secondorder places than will 1,000 first-order places located five miles apart. The minimum required market area for second-order functions would be much larger in the former case. The resulting higher transportation costs would lead to narrower profit margins per sale. Lower profits would decrease the number of firms that could enter the market before either the landscape is completely served or profits are reduced to zero. Fewer second-order firms would mean that fewer second-order cities would be created leading to a high value for $\mathrm{k}$.

Again, a high value for $\mathrm{k}$ means a greater number of complete firstorder cities lying within the market area of each second-order city. The preceeding argument establishes that in some city systems there are fewer second-order cities per first-order city out of necessity. Narrower profit margins caused by low market density result in the requirement of more inclusive market areas for higher order services. The fact that second-order cities in the $\mathrm{k}=7$ model have six complete first-order cities in their market areas instead of two or three (as in the other two models) suggests that cities in the $\mathrm{k}=7$ system need more sheltered market areas. Thus, a region with widely spaced first-order cities will generate

\section{TABLE 6}

Comparison of Southern Central Place System to the $\mathrm{K}=7$ Model

\begin{tabular}{|c|c|c|c|c|}
\hline \multirow[b]{2}{*}{ Order } & \multicolumn{2}{|c|}{ Number of Cities in Eeach Order } & \multicolumn{2}{|c|}{$\begin{array}{c}\text { Distance Separating Cities in the } \\
\text { Same Order }\end{array}$} \\
\hline & Reality & $\mathrm{K}=7$ Model $^{\mathrm{a}}$ & Reality & $\mathrm{K}=7$ Modele \\
\hline 1 & $d$ & 1218 & $13.0^{\mathrm{b}}$ & $13.0^{\mathrm{b}}$ \\
\hline 2 & 146 & 174 & 34.1 & 34.3 \\
\hline 3 & 9,4 & 24 & 94.1 & 91.0 \\
\hline 4 & 4 & 4 & 366.2 & 240.1 \\
\hline 5 & 1 & 1 & - & - \\
\hline
\end{tabular}

aBased on restriction that the location of New Orleans along Gulf coast limited number of fourth-order places to four and the number of third-order places to about twenty-four.

bBased on market radii for gin towns of five to ten miles.

cBased on rule that distances separating $n^{\text {th-order }}$ cities is $\sqrt{7}$ times the distance separating $\mathrm{n}-1$ order places.

dThe exact number of first-order gin towns was never determined. It need only be known that there were several hundred. 
second-order functions which require more inclusive market areas in order to maintain profitability. The result will be a city system patterned after a model with a high $\mathrm{k}$ value.

We need only show that southern first-order cities were relatively widely spaced to explain the high $\mathrm{k}$ value found in the South. To do so statistically would require the identification of first-order cities in the South as well as the North for purposes of comparing the distances separating the cities in the respective regions. Such a measurement would be possible; its method, however, would be so open to question concerning the criteria used to define the first-order cities that the findings would be rendered meaningless. It is not necessary, however, to make such a test to be convinced that the South likely had widely spaced first-order places. The explanation for this arrangement goes back to the basic economic unit, the self-sufficient plantation. The slavemanned plantations of the South were much larger than the farms of the North, including the plains states. Consequently, greater distances separated the primary settlements in the South. The sizeable distances separating farmsteads in the South increased the threshold size of market areas for first-order services. Large market areas for first-order services in all probability caused first-order places in the South to be more widely spaced than similar cities in the North. In accordance with the discussion above, the South naturally and logically produced a city system with a high value for $\mathrm{k}$. The result was a lower absolute level of urbanization in the southern states.

\section{$\mathrm{V}$}

It is never advisable to lean too heavily on central place theory, especially as a model to explain urban development. Nevertheless, the model does provide an excellent framework for studying the rise of an urban network, and in that capacity central place theory can be very informative. Such is the case when analyzing southern urbanization. This study show that viewing urbanization as the development of a central place system can yield many insights into the pace and pattern of urban growth. These insights can tell a great deal about the economic development of a region and can replace the standard generalized statements that simply connect urbanization with industrialization.

\section{FOOTNOTES}

1For all work before 1965 see [9]. Examples of other from 1965 on are [11], [12], [13], [16], [17] and [23].

2The region referred to as the South in this study is the cotton growing area including the states of North Carolina, South Carolina, Georgia, Alabama, Mississippi, Louisiana, Arkansas, and parts of Texas (Eastern) and Tennessee (Western).

3The ring is partial because of the location of New Orleans along the Gulf coast.

4It was found that the southern central place system makes better sense if the twin cities of

Dallas-Fort Worth and Houston-Galveston are treated as single urban centers for years after 1890. In addition, the results of every empirical test on the southern hierarchy of cities and of central functions (e.g., see Table 3) indicate that in many ways the twin cities acted as single central places.

5This pattern of market areas still dominates the southern map as is shown by Walter Isard in Methods of Regional Analysis, page 225 .

${ }_{6}$ This region contains the states of Mississippi, Louisiana, and Arkansas, as well as the eastern half of Texas and the western tip of 
A theoretical deduction can be made from Lösch's model about the reason for the value of $\mathrm{k}$ being high in any particular region: the more widely spaced are the first-order places in a region; the greater is the likelihood for $\mathrm{k}$ to be high. Widely spaced first-order places can lead to fewer and smaller higher order places because transport costs are the primary determinants of the size of market areas and the profitability of supply in the areas. By fewer higher order places I mean a lower number of higher order places per first-order place. A low number of higher order places means a high value for k. For example, 1,000 firstorder places located twenty-five miles apart will support fewer secondorder places than will 1,000 first-order places located five miles apart. The minimum required market area for second-order functions would be much larger in the former case. The resulting higher transportation costs would lead to narrower profit margins per sale. Lower profits would decrease the number of firms that could enter the market before either the landscape is completely served or profits are reduced to zero. Fewer second-order firms would mean that fewer second-order cities would be created leading to a high value for $\mathrm{k}$.

Again, a high value for $\mathrm{k}$ means a greater number of complete firstorder cities lying within the market area of each second-order city. The preceeding argument establishes that in some city systems there are fewer second-order cities per first-order city out of necessity. Narrower profit margins caused by low market density result in the requirement of more inclusive market areas for higher order services. The fact that second-order cities in the $\mathrm{k}=7$ model have six complete first-order cities in their market areas instead of two or three (as in the other two models) suggests that cities in the $\mathrm{k}=7$ system need more sheltered market areas. Thus, a region with widely spaced first-order cities will generate

\section{TABLE 6}

Comparison of Southern Central Place System to the $\mathrm{K}=7$ Model

\begin{tabular}{|c|c|c|c|c|}
\hline \multirow[b]{2}{*}{ Order } & \multicolumn{2}{|c|}{ Number of Cities in Eeach Order } & \multicolumn{2}{|c|}{$\begin{array}{c}\text { Distance Separating Cities in the } \\
\text { Same Order }\end{array}$} \\
\hline & Reality & $\mathrm{K}=7$ Modela & Reality & $\mathrm{K}=7$ Model $\mathrm{c}$ \\
\hline 1 & d & 1218 & $13.0^{\mathrm{b}}$ & $13.0^{\mathrm{b}}$ \\
\hline 2 & 146 & 174 & 34.1 & 34.3 \\
\hline 3 & 9,4 & 24 & 94.1 & 91.0 \\
\hline 4 & 4 & 4 & 366.2 & 240.1 \\
\hline 5 & 1 & 1 & - & - \\
\hline
\end{tabular}

aBased on restriction that the location of New Orleans along Gulf coast limited number of fourth-order places to four and the number of third-order places to about twenty-four.

bBased on market radii for gin towns of five to ten miles.

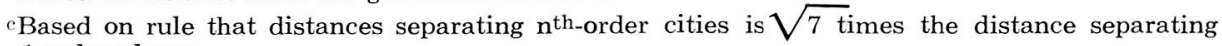
$\mathrm{n}-1$ order places.

dThe exact number of first-order gin towns was never determined. It need only be known that there were several hundred. 
second-order functions which require more inclusive market areas in order to maintain profitability. The result will be a city system patterned after a model with a high $\mathrm{k}$ value.

We need only show that southern first-order cities were relatively widely spaced to explain the high $\mathrm{k}$ value found in the South. To do so statistically would require the identification of first-order cities in the South as well as the North for purposes of comparing the distances separating the cities in the respective regions. Such a measurement would be possible; its method, however, would be so open to question concerning the criteria used to define the first-order cities that the findings would be rendered meaningless. It is not necessary, however, to make such a test to be convinced that the South likely had widely spaced first-order places. The explanation for this arrangement goes back to the basic economic unit, the self-sufficient plantation. The slavemanned plantations of the South were much larger than the farms of the North, including the plains states. Consequently, greater distances separated the primary settlements in the South. The sizeable distances separating farmsteads in the South increased the threshold size of market areas for first-order services. Large market areas for first-order services in all probability caused first-order places in the South to be more widely spaced than similar cities in the North. In accordance with the discussion above, the South naturally and logically produced a city system with a high value for $\mathrm{k}$. The result was a lower absolute level of urbanization in the southern states.

\section{$\mathrm{V}$}

It is never advisable to lean too heavily on central place theory, especially as a model to explain urban development. Nevertheless, the model does provide an excellent framework for studying the rise of an urban network, and in that capacity central place theory can be very informative. Such is the case when analyzing southern urbanization. This study show that viewing urbanization as the development of a central place system can yield many insights into the pace and pattern of urban growth. These insights can tell a great deal about the economic development of a region and can replace the standard generalized statements that simply connect urbanization with industrialization.

\section{FOOTNOTES}

1For all work before 1965 see [9]. Examples of other from 1965 on are [11], [12], [13], [16], [17] and [23].

2The region referred to as the South in this study is the cotton growing area including the states of North Carolina, South Carolina, Georgia, Alabama, Mississippi, Louisiana, Arkansas, and parts of Texas (Eastern) and Tennessee (Western).

${ }^{3}$ The ring is partial because of the location of New Orleans along the Gulf coast.

4It was found that the southern central place system makes better sense if the twin cities of
Dallas-Fort Worth and Houston-Galveston are treated as single urban centers for years after 1890. In addition, the results of every empirical test on the southern hierarchy of cities and of central functions (e.g., see Table 3) indicate that in many ways the twin cities acted as single central places.

5This pattern of market areas still dominates the southern map as is shown by Walter Isard in Methods of Regional Analysis, page 225.

6This region contains the states of Mississippi, Louisiana, and Arkansas, as well as the eastern half of Texas and the western tip of 
Tennessee. Data for the region can be found in Elma S. Moulton, "Cotton Production and Distribution in the Gulf-Southwest," U.S. Department of Commerce, Domestic Commerce Series, No. 49 (Washington, D.C., 1931).

iThe coefficients of determination and Fratios for the variables regressed against market size were:

cottonseed mills: $\quad \mathrm{r}^{2}=.543, \quad \mathrm{~F}=106.9$

cotton presses: $\quad \mathrm{r}^{2}=.143, \quad \mathrm{~F}=14.9$

bale receipts: $\quad \mathrm{r}^{2}=.231, \quad \mathrm{~F}=27.1$

sThe coefficient of determination for the multiple regression is .895 , and the F-ratio of 185.92 indicates that the results are significant at the 99 percent degree of confidence.
9For example South Carolina had just sixteen towns in 1860 but 493 by 1880 . Only three of those 493, however, had populations over 4,000 .

10In 1880 there were less than forty of each in the south. The proliferation of the presses throughout the south was tied to the expanded usage of rail shipping of cotton bales. The discovery of a cheap substitute for olive oil (the price of which was climbing rapidly) led to the explosive growth of the cottonseed oil industry.

11 In 1930 the populations of 4,000 and 20,000 generally described the lower and upper limits of second-order cities.

\section{REFERENCES}

[1] Beavon, K. S. and A. S. Mabin. "The Lösch System of Market Areas: Derivation and Extension," Geographical Analysis, 7 (1975).

[2] Beckman, M. J. "City Hierarchies and the Distribution of City Size," Economic Development and Cultural Change, 6 (1958), 243-8.

[3] Berry, Brian J. L. "City Size Distributions and Economic Development," Economic Development and Cultural Change, 9 (1961), 573-88.

[4] Berry, Brian J. L. and Gardiner H. Barnum. "Aggregate Relations and Elemental Components of Central Place Systems," Journal of Regional Science, 4 (1962), 3568.

[5] Berry, Brian J. L. and William L. Garrison, "A Note on Central Place Theory and the Range of a Good," Economic Geography, 34 (1958), 304-11.

[6] "Alternate Explanations of Urban Rank-Size Relationships, "Annals of the Association of American Geographers, 48 (1958), 83-91.

[7] _. "Recent Developments of Central Place Theory," Paper and Proceedings of the Regional Science Association, 4 (1958), 107-20.

[8]

"The Functional Bases of the Central Place Hierarchy," Economic Geography, 34 (1958), 145-54.

[9] Berry, Brian J. L. and Allen Pred. Central Place Studies: A Bibliography of Theory and Applications (Philadelphia: 1965).

[10] Christaller, Walter. Central Places in Southern Germany, translated by Carlisle W. Bashen (Englewood Cliffs, N.J.: 1966).

[11] Dacey, Michael F. "The Geometry of Central Place Theory," Geografiska Annals, 47-B (1965), 111-124.

[12] . "Population of Places in a Central Place Hierarchy," Journal of Regional Science, 6 (1966), 27-33.

[13] Davies, Wayne K. D. "The Ranking of Service Centers: A Critical Review," Transactions of the Institute of British Geographers, 40 (1966), 51-65.

[14] Hartwick, J. M. "Lösch's Theorem on Hexagonal Market Areas," Journal of $R e$ gional Science, 13 (1973), 213-21.
[15] Henderson, J. V. "Hierarchy Models of City Size: An Economic Evaluation," Journal of Regional Science, 12 (1972).

[16] Higgs, Robert. "Central Place Theory and Regional Urban Hierarchies: An Empirical Note," Journal of Regional Science, 10 (1970), 253-5.

[17] . "The Growth of Cities in a Midwestern Region, 1870-1900," Journal of Regional Science, 9 (1969), 369-75.

[18] Hoover, Edgar M. "The Concept of a System of Cities: A Comment on Rutledge Vining's Paper," Economic Development and Cultural Change, 3 (1955), 196-97.

[19] Lösch, August. The Economics of Location, trans. W. E. Woglam and W. S. Stolper (New Haven, Conn.: Yale University Press, 1954).

[20] "The Nature of Economic Regions," Southern Economic Journal, 5 (1938), 71-78.

[21] Marchand, B. "An Introduction to the Topological Analysis of Geographical Areas: The Topology of Central Place Theory," Geographical Analysis, 5 (1973).

[22] Perloff, H. S. et al. Regions, Resources, and Economic Growth (Baltimore: Johns Hopkins Press, 1960).

[23] Parr, J. B. "City Hierarchies and the Distribution of City Size: A Reconsideration of Beckmann's Contribution," Journal of Regional Science, 9 (1969), 239-53.

[24] Smailes, Arthur E. "The Urban Hierarchy in England and Wales," Geography, 29 (1944), 41-51.

[25] . "The Urban Mesh of England and Wales," Transactions and Papers of the Institute of British Geographers, 12 (1946), 87-101.

[26] Smith, T. Lynn. "The Emergence of Cities," The Urban South, eds., Rupert B. Vance and Nicholas Demerath (Plainview, N.Y.: Books for Libraries, 1954), 24-37.

[27] Tarrant, J. R., "Comments on Lösch's Central Place System," Geographical Analysis, 5 (1973).

[28] Vining, Rutledge. "A Description of Certain Spatial Aspects of an Econcmic System," Economic Development and Cultural Change, 3 (1955), 147-95. 